\title{
Efficient Removal of Lead, Copper and Cadmium Ions from Water by a Porous Calcium Alginate/Graphene Oxide Composite Aerogel
}

\author{
Linhai Pan ${ }^{1}$, Zhuqing Wang ${ }^{1,2, * \mathbb{D}}$, Qi Yang ${ }^{1}$ and Rongyi Huang ${ }^{1}$ \\ 1 AnHui Provice Key Laboratory of Optoelectronic and Magnetism Functional Materials, \\ Anqing Normal University, Anqing 246011, China; panlinhai@nimte.ac.cn (L.P.); \\ wangzhq@aqnu.edu.cn (Q.Y.); huangry@aqnu.edu.cn (R.H.) \\ 2 Faculty of Production Engineering, University of Bremen, Am Fallturm 1, D-28359 Bremen, Germany \\ * Correspondence: wzhuqing@uni-bremen.de; Tel.: +49-421-218-64581
}

Received: 1 November 2018; Accepted: 17 November 2018; Published: 20 November 2018

\begin{abstract}
In this study, we fabricated a porous calcium alginate/graphene oxide composite aerogel by using polystyrene colloidal particles as sacrificial template and graphene oxide as a reinforcing filler. Owing to the excellent metal chelation ability of calcium alginate and controlled nanosized pore structure, the as-prepared calcium alginate/graphene oxide composite aerogel (mp-CA/GO) can reach the adsorption equilibrium in $40 \mathrm{~min}$, and the maximum adsorption capacity for $\mathrm{Pb}^{2+}, \mathrm{Cu}^{2+}$ and $\mathrm{Cd}^{2+}$ is $368.2,98.1$ and $183.6 \mathrm{mg} / \mathrm{g}$, respectively. This is higher than most of the reported heavy metal ion sorbents. Moreover, the $\mathrm{mp}-\mathrm{CA} / \mathrm{GO}$ can be regenerated through simple acid-washing and be used repeatedly with little loss in performance. The adsorption mechanism analysis indicates that the mp-CA/GO adsorb the heavy metal ions mainly through the ion exchange and chemical coordination effects.
\end{abstract}

Keywords: Adsorbent; heavy metal ions; calcium alginate; graphene oxide; polystyrene colloidal particles template

\section{Introduction}

Heavy metal pollution is currently a serious environmental problem. Heavy metal ions are not biodegradable and tend to accumulate in living organisms, thereby causing many serious health and environment problems [1,2]. Therefore, it is of great significance to remove heavy metal ions in water. In recent years, many methods such as ion-exchange, chemical oxidation and reduction, membrane filtration, chemical precipitation, and adsorption have been employed for removing heavy metal ions from water media [3-7]. Among these treatment methods, adsorption attracts more attention due to its simple operation, low price, recyclability of the adsorbent, and high efficiency in treating low-concentration wastewater [8].

The exploration of efficient adsorbent materials starts by providing additional binding sites for adsorbed ions, improving the diffusion coefficient during the adsorption process, and enhancing the overall mechanical properties of adsorbent materials. Adsorbents with a large specific surface area, additional active groups, such as carboxyl and hydroxyl groups, and rational diffusion path for metal ion during adsorption are required. Deze et al. demonstrated the effect of porosity in heavy metal ions sorption [9].

In our previous work, we synthesized pure calcium alginate and chitosan-calcium alginate hybrid aerogels for removing heavy metal ions in water $[10,11]$. The results showed that calcium alginate could efficient removal of $\mathrm{Pb}^{2+}$ and $\mathrm{Cu}^{2+}$ from wastewater due to its rich carboxyl (-COOH) and hydroxyl 
$(-\mathrm{OH})$ groups. However, dry alginate bead that has been used for heavy metal ion sorption is a rigid material without controlled porous structure, and given the low diffusion coefficient of the material, the sorption kinetics is relatively slow. Furthermore, pure alginate also exhibits several unsatisfactory structural properties, such as weak mechanical strength, structural instability, and fragile collapse [12], thus limiting their applications in the actual setting.

Graphene oxide (GO) is a new carbon material with excellent properties, high specific surface area, and rich surface functional groups. GO also exhibits a considerable potential in reinforcing fillers given its outstanding mechanical properties, excellent binding capacity, and superior flexibility [13]. The unsatisfactory properties of alginate structure and collapse of a porous material structure can be easily solved by adding GO sheets as ideal reinforcing fillers for composites. Jiao et al. presented that GO, as a reinforcing filler, exhibits excellent mechanical strength and elasticity in adsorbing heavy metal ions [13]. Recently, Yang et al. successfully prepared double network hydrogel beads by directly mixing GO and sodium alginate solutions. The as-prepared hydrogel beads showed good affinity to cationic metals and the theoretical maximum adsorption capacity for $\mathrm{Mn}^{2+}$ reached $56.49 \mathrm{mg} / \mathrm{g}$ [14]. However, preparing adsorbent materials with controlled pore structure and excellent mechanical properties has not been reported.

In this study, a novel macro-porous ( $\mathrm{mp}$ ) calcium alginate/graphene oxide composite aerogel (mp-CA/GO) with controlled pore structure was prepared by introducing macropores within the composite aerogel using polystyrene (PS) colloidal particles as sacrificial template and GO as reinforcing fillers. The as-prepared mp-CA/GO was characterized and used for heavy metal ions $\left(\mathrm{Pb}^{2+}\right.$, $\mathrm{Cu}^{2+}$ and $\mathrm{Cd}^{2+}$ ) sorption. In addition, adsorption capacity, kinetics and thermodynamics properties, adsorption mechanism, and reutilization were also explored.

\section{Materials and Methods}

\subsection{Materials}

Sodium alginate, ethanol, styrene, potassium persulfate $\left(\mathrm{K}_{2} \mathrm{~S}_{2} \mathrm{O}_{8}\right)$, nitric acid $\left(\mathrm{HNO}_{3}\right), \mathrm{GO}$ suspension (in water), sodium chloride $(\mathrm{NaCl})$, and other metal salts were bought from Shanghai Aladdin Biochemical Technology Co. Ltd. (Shanghai, China). Certain reagents such as styrene, potassium persulfate, and sodium chloride, were used with further purification. High concentration GO suspension was diluted with deionized (DI) water, and DI water was used throughout this study.

\subsection{Instruments}

Scanning electron microscopy (SEM) images were obtained on a Sirion200 microscope (FEI Company, Eindhoven, the Netherlands) at an accelerating voltage of $10.0 \mathrm{kV}$. The infrared spectra were obtained from a Nicolet 6700 Fourier transform infrared (FT-IR) spectrometer (Thermo Fisher Scientific, Waltham, MA, USA). X-ray diffraction (XRD) pattern was collected on a Bruker axs D8 advanced diffractometer (Bruker Corporation, Frankfurt, Germany) using $\mathrm{Cu} \mathrm{K} \alpha$ radiation. X-ray photoelectron spectroscopy (XPS) spectra were collected on a Shimadzu Axis-Ultra multifunctional X-ray photoelectron spectrometer (Shimadzu Corporation, Tokyo, Japan) using an Al K X-ray source. Metal concentrations were confirmed using a Perkin-Elmer Optima 2100 (Perkin-Elmer Company, Waltham, MA, USA) inductively coupled plasma-optical emission spectrometry (ICP-OES).

\subsection{Preparation of PS Colloidal Particles}

Monodisperse PS colloidal particles were synthesized by soapless emulsion polymerization [15]. Styrene is purified by vacuum distillation before using $150 \mathrm{~mL}$ of DI water, $0.175 \mathrm{~g}$ sodium chloride and $25 \mathrm{~g}$ styrene were added into a $250 \mathrm{~mL}$ three-port bottle, and stirred in the water bath at $70^{\circ} \mathrm{C}$. Then, $0.2 \mathrm{~g}$ of $\mathrm{K}_{2} \mathrm{~S}_{2} \mathrm{O}_{8}$ was added to the bottle after ventilating nitrogen for nearly $20 \mathrm{~min}$. With nitrogen protection, the polymerization reaction was conducted at $70^{\circ} \mathrm{C}$ for $20 \mathrm{~h}$. After the reaction, the particles were subjected to repeated centrifugal sedimentation at $9000 \mathrm{rpm}$ and ultrasonic dispersion in water 
and ethanol to remove the styrene monomer and sodium chloride. Finally, the PS particles were mixed into a solution with $10 \%$ mass fraction.

\subsection{Preparation of $m p-C A / G O$}

For the fabrication of the mp-CA/GO, the GO $\left(0.5 \mathrm{mg} \mathrm{mL}^{-1}, 2 \mathrm{~mL}\right)$ and sodium alginate $(1 \%$ $w / v, 20 \mathrm{~mL})$ solutions were mixed homogeneously. Then, PS colloidal particles solution $(0.5 \mathrm{~mL}$, $10 \mathrm{wt} . \%)$ was added to the sodium alginate and GO mixed solutions under magnetic stirring to form a homogeneous mixture. After that, this mixed solution was added dropwise to $100 \mathrm{~mL}$ of $0.2 \mathrm{M}$ $\mathrm{Ca}^{2+}$ solution. A hydrogel sphere formed immediately when the mixed solution contacted with the $\mathrm{Ca}^{2+}$ solution. The hydrogel spheres were collected and washed with DI water, and placed into a low-temperature freezer. Then, the frozen hydrogel spheres were freeze-dried for $24 \mathrm{~h}$ under vacuum. The final mp-CA/GO composite aerogel were obtained by removing the PS colloidal particles with toluene and tetrahydrofuran exposure through ultrasonication [16].

\subsection{Adsorption and Desorption Tests}

In an adsorption test, $\sim 50 \mathrm{mg}$ of $\mathrm{mp}-\mathrm{CA} / \mathrm{GO}$ was added to $50 \mathrm{~mL}$ of $1.5 \mathrm{mM} \mathrm{Pb}^{2+}, \mathrm{Cu}^{2+}$, and $\mathrm{Cd}^{2+}$ solutions, respectively. The mixture was filtered after stirring for $40 \mathrm{~min}$. The unextracted $\mathrm{Pb}^{2+}$, $\mathrm{Cu}^{2+}$, and $\mathrm{Cd}^{2+}$ in the filtrate were determined by ICP-OES.

In the desorption test, the $\mathrm{Pb}^{2+}{ }_{-}, \mathrm{Cu}^{2+}-$, or $\mathrm{Cd}^{2+}$-loaded mp-CA/GO was first immersed in $50 \mathrm{~mL}$ of $0.07 \mathrm{M} \mathrm{HNO}_{3}$ solution for $20 \mathrm{~min}$. Then, the mp-CA/GO was separated and washed with DI water. The desorbed $\mathrm{Pb}^{2+}, \mathrm{Cu}^{2+}$, and $\mathrm{Cd}^{2+}$ in the eluent were also determined by ICP-OES. Each adsorption or desorption test was performed three times in parallel. The metal ion concentration was also determined three times in parallel and then averaged.

The adsorption capacity $(Q, \mathrm{mg} / \mathrm{g})$ and Adsorption $(\%)$ were calculated as follows:

$$
\begin{gathered}
Q=\frac{\left(C_{i}-C_{f}\right) \cdot V \cdot M}{m} \\
\text { Adsorption }=\frac{\left(C_{i}-C_{f}\right)}{C_{i}} \times 100 \%
\end{gathered}
$$

where $V$ is the volume of the solution (L); $m$ is the weight of the mp-CA/GO (g); $M$ is the molar mass of metals $\left(\mathrm{g} \mathrm{mol}^{-1}\right)$; and $C_{i}$ and $C_{f}$ represent the initial and final concentration of metal ions in solution, respectively $(\mathrm{mM})$.

\section{Results and Discussion}

\subsection{Material Characterizations}

Figure 1A illustrates the GO and PS suspensions that were used to prepare the mp-CA/GO. PS colloidal particle suspension appears milky white, whereas GO suspension appear brownish black due to high concentration. GO and PS can be dispersed in DI water and form homogeneous suspensions after a mild ultrasonic treatment. The XRD pattern of GO is presented in Figure 1D. The strong diffraction peak of GO appears at $11.5^{\circ}$, which can be indexed to the (002) reflections of stacked GO sheets with the interlayer distance of $0.771 \mathrm{~nm}$, which allows alginate to exist between layers of GO [17-19]. The mp-CA/GO with excellent mechanical strength and structural stability was acquired by the help of GO. The morphology of PS and GO was characterized by SEM, as depicted in Figure 1B,C. The surface of the GO film has noticeable folds, which are attributed to the flexible, ultra-thin 2D lamination of GO (Figure 1C). As the most commonly used template material, PS colloidal particles have an excellent uniformity with a diameter of ca. $720 \mathrm{~nm}$ (Figure 1B), this uniformity is important for preparing materials with controlled porous structures. 

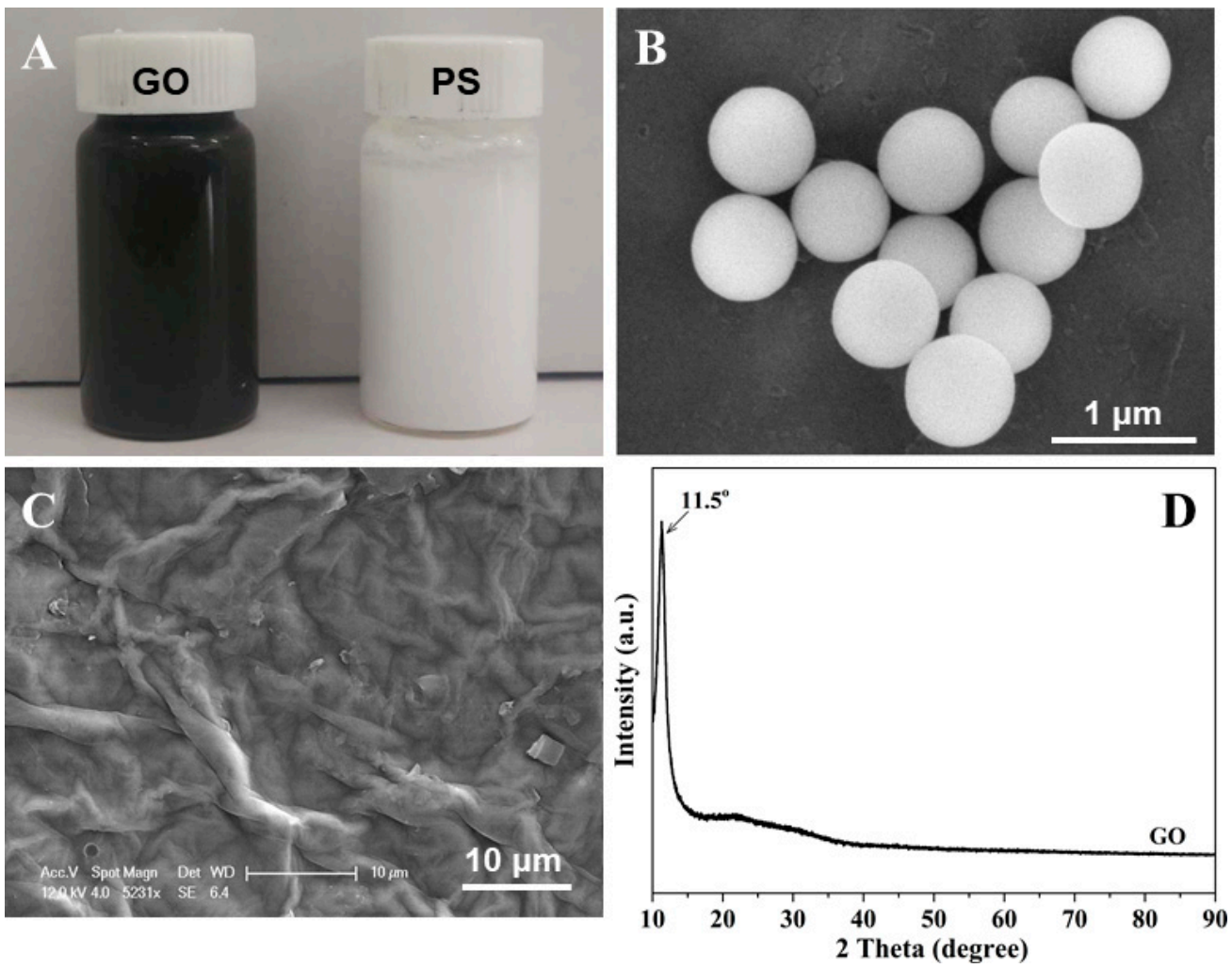

Figure 1. (A) Digital photo of GO and PS solutions, SEM images of (B) PS colloidal particles and (C) GO film, and (D) XRD pattern of GO.

The FT-IR spectra of GO, calcium alginate (CA) and mp-CA/GO are presented in Figure 2. In the three spectra, the absorption peaks around 3360 and $1412 \mathrm{~cm}^{-1}$ are ascribed to the $\mathrm{O}-\mathrm{H}$ and $-\mathrm{COOH}$, respectively. The weak peak around $2930 \mathrm{~cm}^{-1}$ in the spectra of CA and mp-CA/GO belongs to the asymmetric stretching vibration of $\mathrm{C}-\mathrm{H}$, in which the "egg-box" structures formed by sodium alginate macromolecule and calcium ion limit the $\mathrm{C}-\mathrm{H}$ stretching $[20,21]$. The peaks at 3179, 1715 and $1620 \mathrm{~cm}^{-1}$ in the spectrum of $\mathrm{GO}$ are attributed to the stretching vibrations of $-\mathrm{OH},-\mathrm{COOH}$ and $\mathrm{C}=\mathrm{C}$ in the $\mathrm{sp}^{2}$ carbon skeletal network, respectively [22]. Compared with the pure GO, the peaks of mp-CA/GO downshift from 3380 to $3346 \mathrm{~cm}^{-1}$ and 1612 to $1599 \mathrm{~cm}^{-1}$, respectively. It can be attributed to the intermolecular hydrogen bonds formed between GO sheets and alginate [23].

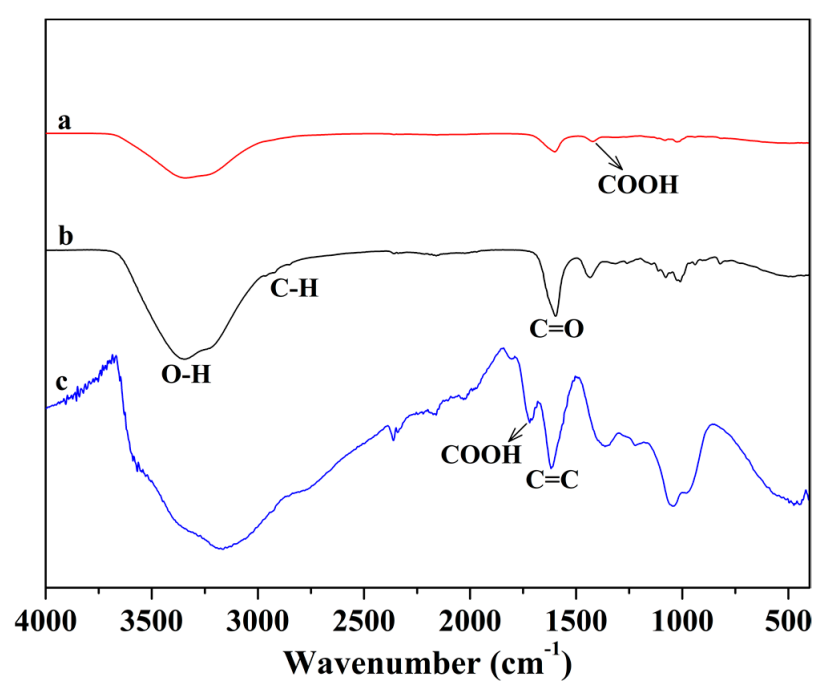

Figure 2. FT-IR spectra of (a) mp-CA/GO, (b) CA and (c) GO. 
The SEM photos of the mp-CA/GO and CA are displayed in Figure 3. The PS beads with a diameter of ca. $720 \mathrm{~nm}$ are homogeneously dispersed in a composite aerogel sphere (Figure 3A), the spaces that were originally occupied by the PS beads remain as macropores after removing the particle template, and $\mathrm{mp}-\mathrm{CA} / \mathrm{GO}$ has a uniform diameter of approximately $720 \mathrm{~nm}$ macropore (Figure 3B). The surface appears more uneven in the mp-CA/GO with controlled pore structure than CA (Figure 3C), this phenomenon is beneficial to adsorb metal ions. In addition, the diameter of the pore structure can be regulated by changing the diameter of PS colloidal particle template, thus allowing us to design the required pore size of materials.
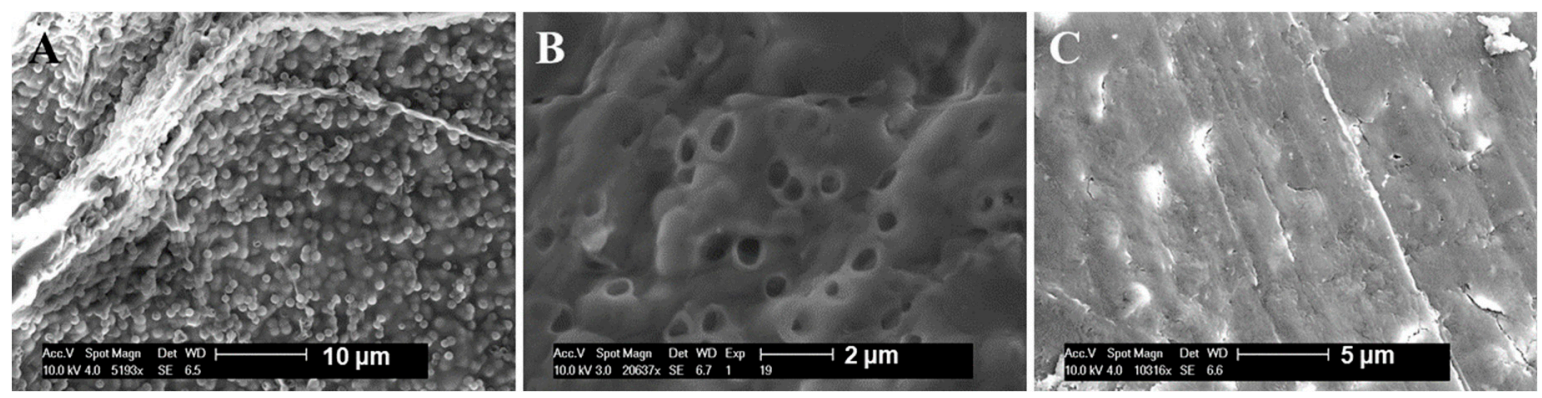

Figure 3. SEM photos of (A,B) mp-CA/GO/CA and (C) CA.

\subsection{Effect of $p H$}

In order to evaluate the effect of $\mathrm{pH}$ on adsorption performance, we conducted experiments at $\mathrm{pH}$ values that range from one to seven. As can be seen in Figure 4, adsorption capacity of the as-prepared mp-CA/GO increased significantly when the $\mathrm{pH}$ increased from one to three, and then remained stable with a further increase in $\mathrm{pH}$. This result can be due to the change in the ionic state of the amino and carboxyl groups. When the mp-CA/GO was in strong acidic circumstance $(\mathrm{pH}<3)$, functional groups (amino and carboxyl) were protonated. However, amino and carboxyl groups are deprotonated with an increase in the solution $\mathrm{pH}(3 \leq \mathrm{pH} \leq 7)[10,24]$. Therefore, $\mathrm{mp}-\mathrm{CA} / \mathrm{GO}$ has wide $\mathrm{pH}$ range to meet the needs of real application.

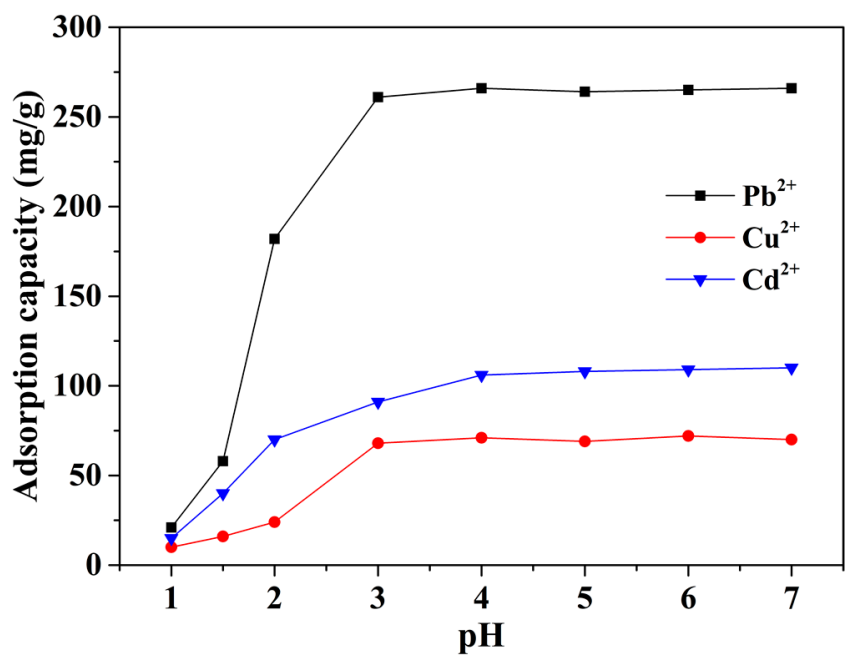

Figure 4. Effect of $\mathrm{pH}$ on metal ions adsorption. ( $50 \mathrm{mg}$ of $\mathrm{mp}-\mathrm{CA} / \mathrm{GO}$ was equilibrated with $50 \mathrm{~mL}$ of $1.5 \mathrm{mM} \mathrm{Pb}^{2+}, \mathrm{Cu}^{2+}$, or $\mathrm{Cd}^{2+}$ at $25^{\circ} \mathrm{C}$ for $\left.40 \mathrm{~min}\right)$.

\subsection{Effect of the Contact Time and Environmental Temperature}

The effect of contact time on the adsorption behavior of mp-CA/GO was also evaluated (Figure 5). The adsorption rate of $\mathrm{Pb}^{2+}, \mathrm{Cu}^{2+}$, and $\mathrm{Cd}^{2+}$ onto the mp-CA/GO was quite fast, thereby completing the adsorption process within $40 \mathrm{~min}$. The adsorption rate was clearly high at the 
initial adsorption period, possibly due to the controlled porous structures and abundant vacant sites of aerogel. The diffusion rate of metal ions was accelerated through the nanoporous structure of $\mathrm{mp}-\mathrm{CA} / \mathrm{GO}$, thereby indicating the primary objective of preparing porous structure using PS colloidal particles as template. Furthermore, pseudo-first-order and pseudo-second-order kinetic models have been employed to investigate the adsorption kinetics during the adsorption process. The results summarized in Table 1 show that the pseudo-second-order kinetic model fits well with the kinetic data according to the values of $\mathrm{R}^{2}$, thus suggesting that chemical sorption is a rate determining step in the adsorption process.
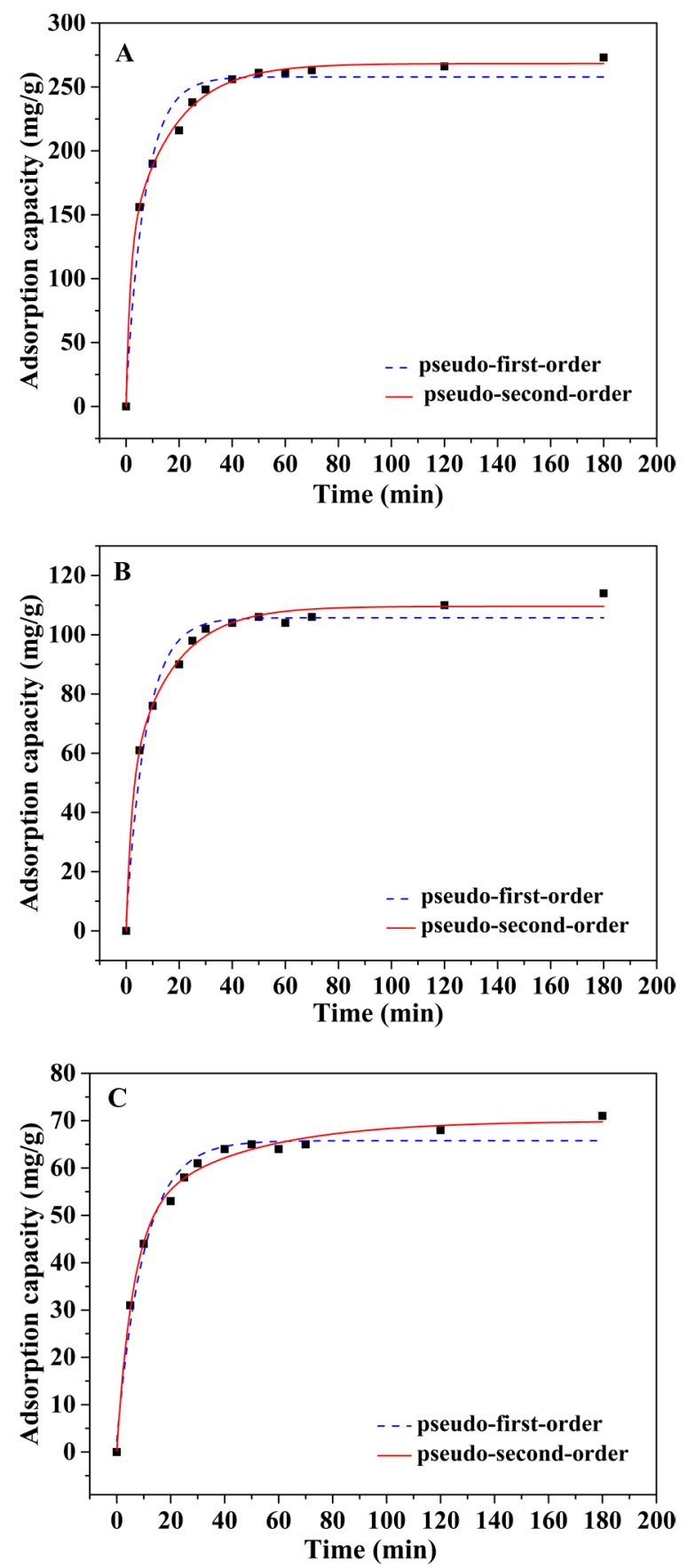

Figure 5. Adsorption kinetics studies of the $(\mathbf{A}) \mathrm{Pb}^{2+},(\mathbf{B}) \mathrm{Cd}^{2+}$, and (C) $\mathrm{Cu}^{2+}$. ( $50 \mathrm{mg}$ of mp-CA/GO was equilibrated with $50 \mathrm{~mL}$ of $1.5 \mathrm{mM} \mathrm{Pb}^{2+}, \mathrm{Cu}^{2+}$, or $\mathrm{Cd}^{2+}$ solution at $\left.25^{\circ} \mathrm{C}\right)$. 
Table 1. Kinetic parameters for $\mathrm{Pb}^{2+}, \mathrm{Cd}^{2+}$, and $\mathrm{Cu}^{2+}$ ions adsorption on the mp-CA/GO.

\begin{tabular}{cccccc}
\hline Kinetic Model & Formula & Parameters & $\mathbf{P b}^{2+}$ & $\mathbf{C u}^{2+}$ & $\mathbf{C d}^{2+}$ \\
\hline pseudo-first-order & $\mathrm{q}_{\mathrm{t}}=\mathrm{q}_{\mathrm{e}}\left(1-\exp \left(-\mathrm{k}_{1} \mathrm{t}\right)\right)$ & $\mathrm{q}_{\mathrm{e}}\left(\mathrm{mg} \mathrm{g}^{-1}\right)$ & 257.849 & 65.779 & 105.737 \\
& & $\mathrm{k}_{1}\left(\mathrm{~L} \mathrm{~min}^{-1}\right)$ & 0.158 & 0.124 & 0.113 \\
& & $\mathrm{R}^{2}$ & 0.962 & 0.975 & 0.968 \\
\hline pseudo-second-order & $\mathrm{q}_{\mathrm{t}}=\mathrm{q}_{\mathrm{e}}\left(1-1 /\left(1+\mathrm{q}_{\mathrm{e}} \mathrm{k}_{2} \mathrm{t}\right)\right)$ & $\mathrm{q}_{\mathrm{e}}\left(\mathrm{mg} \mathrm{g}^{-1}\right)$ & 268.284 & 69.985 & 109.589 \\
& & $\mathrm{k}_{2}\left(\mathrm{~L} \mathrm{~min}^{-1}\right)$ & 0.004 & 0.002 & 0.002 \\
& & $\mathrm{R}^{2}$ & 0.996 & 0.992 & 0.991 \\
\hline
\end{tabular}

Furthermore, the effect of environmental temperature on the adsorption behavior for heavy metal ions was also investigated. As seen in Figure 6, the adsorption capacity of the mp-CA/GO increased slowly with the increase in temperature. However, its improvement in terms of adsorption performance was vague, possibly because the large specific surface area and controlled porous structure of $\mathrm{mp}-\mathrm{CA} / \mathrm{GO}$ allowed the metal ions to acquire additional binding sites and rapid ion diffusion rate on the material. The adsorbent's weak sensitivity to temperature is crucial to practical applications, thereby enabling the mp-CA/GO to be potentially applied to the practical treatment of heavy metal ions.

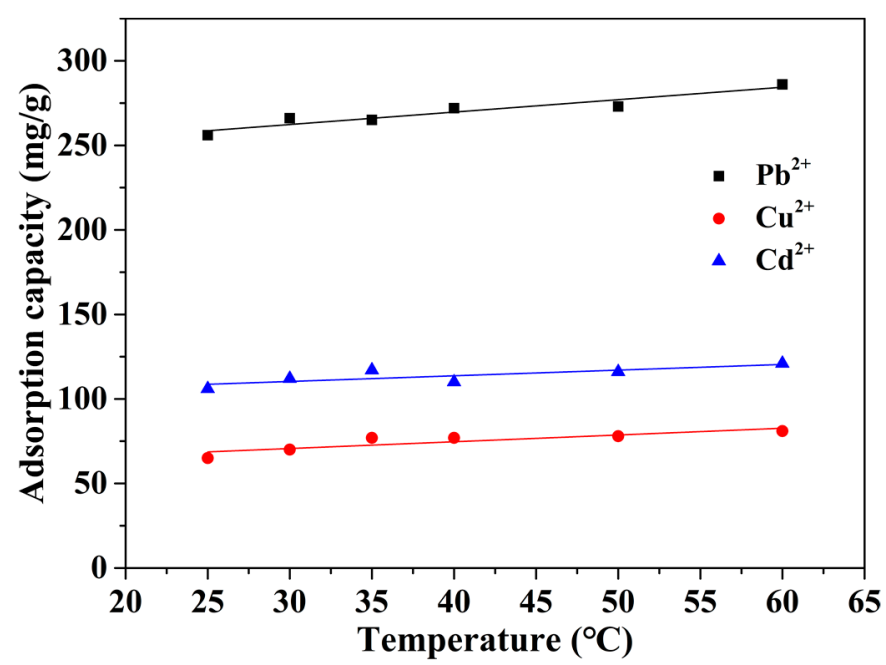

Figure 6. Effect of the environmental temperature on metal ions adsorption. ( $50 \mathrm{mg}$ of $\mathrm{mp}-\mathrm{CA} / \mathrm{GO}$ was equilibrated with $50 \mathrm{~mL}$ of $1.5 \mathrm{mM} \mathrm{Pb}^{2+}, \mathrm{Cu}^{2+}$, or $\mathrm{Cd}^{2+}$ solution at different temperatures for $40 \mathrm{~min}$ ).

\subsection{Maximum Adsorption Capacity of the mp-CA/GO}

The maximum adsorption capacity is one of the most important features for the adsorbent. As seen in Figure 7, the adsorption capacity increases dramatically with the initial concentration from $0.1 \mathrm{mM}$ to four $\mathrm{mM}$ for the $\mathrm{mp}-\mathrm{CA} / \mathrm{GO}$. After exceeding four $\mathrm{mM}$, the increment in mp-CA/GO has leveled off, possibly because of the lack of adequate functional groups to accommodate additional metal ions. The maximum adsorption capacities of mp-CA/GO for $\mathrm{Pb}^{2+}, \mathrm{Cu}^{2+}$, and $\mathrm{Cd}^{2+}$ are 368.2 , 98.1 and $183.6 \mathrm{mg} / \mathrm{g}$, respectively. These values are higher than most of the reported heavy metal ion adsorbents [25-43] (Table 2). 


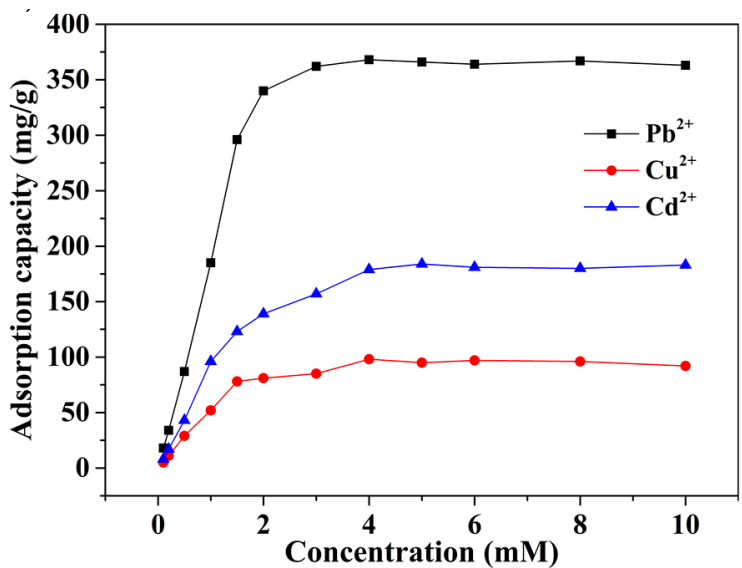

Figure 7. Effect of the initial metal ion concentration on adsorption. ( $\sim 50 \mathrm{mg}$ of mp-CA/GO was equilibrated with $50 \mathrm{~mL}$ of $\mathrm{Pb}^{2+}, \mathrm{Cu}^{2+}$, or $\mathrm{Cd}^{2+}$ solution at $25^{\circ} \mathrm{C}$ for $40 \mathrm{~min}$ ).

Table 2. Comparison of adsorption capacity of various adsorbent for $\mathrm{Pb}^{2+}, \mathrm{Cu}^{2+}$, and $\mathrm{Cd}^{2+}$.

\begin{tabular}{|c|c|c|c|c|}
\hline Adsorbent & Heavy Metals (Adsorbate) & $\begin{array}{l}\text { Maximum Adsorption } \\
\text { Capacity }(\mathrm{mg} / \mathrm{g})\end{array}$ & $\begin{array}{c}\text { Year of } \\
\text { Publication }\end{array}$ & Reference \\
\hline Amino functionalized mesoporous silica & $\mathrm{Pb}^{2+}, \mathrm{Ni}^{2+}, \mathrm{Cd}^{2+}$ & $\begin{array}{c}57.7\left(\mathrm{~Pb}^{2+}\right), 12.4\left(\mathrm{Ni}^{2+}\right), 18.3 \\
\left(\mathrm{Cd}^{2+}\right)\end{array}$ & 2009 & [25] \\
\hline Nano-alumina & $\mathrm{Pb}^{2+}, \mathrm{Cr}^{3+}, \mathrm{Cd}^{2+}$ & $\begin{array}{c}100.0\left(\mathrm{~Pb}^{2+}\right), 100.0\left(\mathrm{Cr}^{3+}\right) \\
83.3\left(\mathrm{Cd}^{2+}\right)\end{array}$ & 2010 & [26] \\
\hline $\begin{array}{l}\text { Amino functionalized magnetic } \\
\text { graphenes composite }\end{array}$ & $\mathrm{Pb}^{2+}, \mathrm{Hg}^{2+}, \mathrm{Cr}^{6+}, \mathrm{Cd}^{2+}$ & $\begin{array}{c}28.0\left(\mathrm{~Pb}^{2+}\right), 23.0\left(\mathrm{Hg}^{2+}\right), 17.3 \\
\left(\mathrm{Cr}^{6+}\right), 27.8\left(\mathrm{Cd}^{2+}\right)\end{array}$ & 2014 & [27] \\
\hline Polydopamine microspheres & $\mathrm{Pb}^{2+}$ & 165.8 & 2017 & {$[28]$} \\
\hline $\begin{array}{c}\text { Polyving alcohol/polyacrylic acid double } \\
\text { network gel }\end{array}$ & $\mathrm{Pb}^{2+}, \mathrm{Cd}^{2+}$ & $195.0\left(\mathrm{~Pb}^{2+}\right), 115.9\left(\mathrm{Cd}^{2+}\right)$ & 2015 & [29] \\
\hline Biochar-alginate capsule & $\mathrm{Pb}^{2+}$ & 263.2 & 2013 & {$[30]$} \\
\hline Polyaniline/calcium alginate composite & $\mathrm{Pb}^{2+}, \mathrm{Cu}^{2+}$ & $357.0\left(\mathrm{~Pb}^{2+}\right), 79.0\left(\mathrm{Cu}^{2+}\right)$ & 2012 & [31] \\
\hline $\begin{array}{l}\text { Silica modified calcium alginate-xanthan } \\
\text { gum hybrid bead composite }\end{array}$ & $\mathrm{Pb}^{2+}$ & 18.9 & 2013 & [32] \\
\hline $\begin{array}{l}\text { Activated carbon-calcium alginate } \\
\text { composite }\end{array}$ & $\mathrm{Pb}^{2+}$ & 15.7 & 2016 & [33] \\
\hline Alginate-SBA-15 composite & $\mathrm{Pb}^{2+}$ & 222.2 & 2013 & {$[34]$} \\
\hline Soy protein hollow microspheres & $\begin{array}{l}\mathrm{Pb}^{2+}, \mathrm{Zn}^{2+}, \mathrm{Cr}^{3+}, \mathrm{Cd}^{2+} \\
\mathrm{Cu}^{2+}, \mathrm{Ni}^{2+}\end{array}$ & $\begin{array}{c}235.6\left(\mathrm{~Pb}^{2+}\right), 255.0\left(\mathrm{Zn}^{2+}\right) \\
52.9\left(\mathrm{Cr}^{3+}\right), 120.8\left(\mathrm{Cd}^{2+}\right) \\
115.0\left(\mathrm{Cu}^{2+}\right), 177.1\left(\mathrm{Ni}^{2+}\right)\end{array}$ & 2013 & [35] \\
\hline Magnetic alginate beads & $\mathrm{Pb}^{2+}$ & 50 & 2012 & {$[36]$} \\
\hline$\gamma$ - $\mathrm{Fe}_{2} \mathrm{O}_{3}$ nanoparticles & $\mathrm{Pb}^{2+}, \mathrm{Cu}^{2+}$ & $69.0\left(\mathrm{~Pb}^{2+}\right), 34.0\left(\mathrm{Cu}^{2+}\right)$ & 2017 & [37] \\
\hline $\begin{array}{l}\text { Magnetic chitosan/graphene oxide } \\
\text { imprinted } \mathrm{Pb}^{2+}\end{array}$ & $\mathrm{Pb}^{2+}$ & 79.0 & 2016 & [37] \\
\hline Chitosan coated calcium alginate & $\mathrm{Pb}^{2+}$ & 106.9 & 2016 & [39] \\
\hline $\begin{array}{c}\text { Hydroxyapatite/chitosan porous } \\
\text { material }\end{array}$ & $\mathrm{Pb}^{2+}$ & 264.4 & 2015 & {$[40]$} \\
\hline $\begin{array}{c}\text { Calcite-poly(ethyleneimine) } \\
\text { nanostructured rod }\end{array}$ & $\mathrm{Pb}^{2+}$ & 240 & 2013 & {$[41]$} \\
\hline $\begin{array}{c}\text { Nanostructured } \\
\text { vaterite-poly(ethyleneimine) hybrid }\end{array}$ & $\mathrm{Pb}^{2+}$ & 2762 & 2014 & {$[42]$} \\
\hline Alginate-melamine hybrid & $\mathrm{Pb}^{2+}$ & 287.7 & 2018 & {$[43]$} \\
\hline $\mathrm{mp}-\mathrm{CA} / \mathrm{GO}$ & $\mathrm{Pb}^{2+}, \mathrm{Cu}^{2+}, \mathrm{Cd}^{2+}$ & $\begin{array}{c}368.2\left(\mathrm{~Pb}^{2+}\right), 98.1\left(\mathrm{Cu}^{2+}\right) \\
183.6\left(\mathrm{Cd}^{2+}\right)\end{array}$ & This work & This work \\
\hline
\end{tabular}

To study the adsorption behavior and predict which adsorption system is favorable. Langmuir adsorption isotherm and Freundlich adsorption isotherm models were applied in this study (Figure 8). The isotherm constants were calculated from the experimental data and are presented in Table 3. 
The results show that the Langmuir isotherm appears to be a favorable model to supervise the adsorption process, which indicates the adsorption process was a monolayer adsorption.
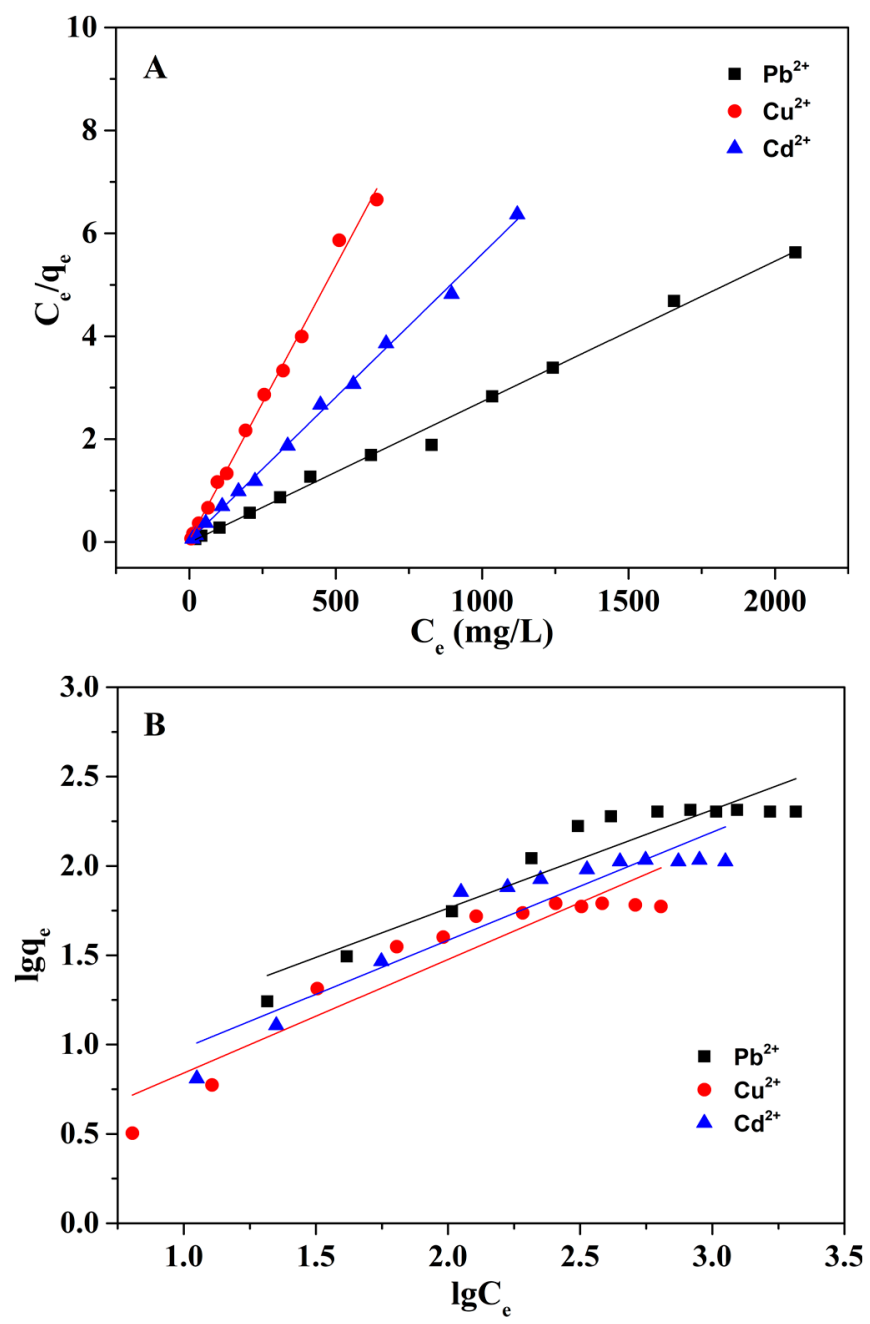

Figure 8. (A) Langmuir and (B) Freundlich adsorption isotherms studies of the $\mathrm{Pb}^{2+}, \mathrm{Cd}^{2+}$, and $\mathrm{Cu}^{2+}$. ( $50 \mathrm{mg}$ of $\mathrm{mp}-\mathrm{CA} / \mathrm{GO}$ was equilibrated with $50 \mathrm{~mL}$ of $\mathrm{Pb}^{2+}, \mathrm{Cu}^{2+}$, or $\mathrm{Cd}^{2+}$ solution at $25^{\circ} \mathrm{C}$ for $40 \mathrm{~min})$.

Table 3. Isotherm parameters for $\mathrm{Pb}^{2+}, \mathrm{Cd}^{2+}$, and $\mathrm{Cu}^{2+}$ ions adsorption on the mp-CA/GO.

\begin{tabular}{cccccc}
\hline Isotherm Model & Formula & Parameters & $\mathbf{P b}^{\mathbf{2 +}}$ & $\mathbf{C u}^{2+}$ & $\mathbf{C d}^{\mathbf{2 +}}$ \\
\hline Langmuir & $\mathrm{C} / \mathrm{q}=\mathrm{C} / \mathrm{q}_{\mathrm{e}}+1 /(\mathrm{q} \mathrm{b})$ & $\mathrm{q}(\mathrm{mg} / \mathrm{g})$ & 366.835 & 180.274 & 96.693 \\
& & $\mathrm{~b}(\mathrm{~L} / \mathrm{mg})$ & 0.493 & 0.473 & 0.415 \\
& & $\mathrm{R}^{2}$ & 0.994 & 0.998 & 0.995 \\
\hline Freundlich & $\mathrm{lgq}=\operatorname{lgK}+1 / \mathrm{nlgC}$ & $\mathrm{K}(\mathrm{L} / \mathrm{mg})$ & 5.263 & 3.863 & 3.573 \\
& & $\mathrm{n}$ & 2.163 & 1.663 & 1.862 \\
& & $\mathrm{R}^{2}$ & 0.878 & 0.873 & 0.864 \\
\hline
\end{tabular}

\subsection{Adsorption Mechanism}

In order to clarify the adsorption mechanism of the mp-CA/GO, we monitored the amount of each metal ion in the adsorption process. It can be seen from Figure 9 that the mole amount of $\mathrm{Pb}^{2+}, \mathrm{Cu}^{2+}$ and $\mathrm{Cd}^{2+}$ in the solution decreased while $\mathrm{Ca}^{2+}$ increased as the reaction proceeded. This illustrates that, in the first adsorption process, the adsorption of heavy metal ions is mainly completed by ion exchange. However, the mole amount of the adsorbed $\mathrm{Pb}^{2+}, \mathrm{Cu}^{2+}$, or $\mathrm{Cd}^{2+}$ is higher than that of the 
desorbed $\mathrm{Ca}^{2+}$ during the different adsorption periods, indicating that the ion exchange is only one of the mechanisms. In order to fully understand the essence of adsorption, we further analyzed the $\mathrm{O}$ one s spectra before and after $\mathrm{Pb}^{2+}, \mathrm{Cu}^{2+}$, and $\mathrm{Cd}^{2+}$ adsorption (Figure 10). The two peaks at 530.88 and $529.767 \mathrm{eV}$ in the $\mathrm{O}$ one s spectrum are attributed to the oxygen-containing functional groups. New peaks appeared at 530.461, 530.728, and $530.866 \mathrm{eV}$, respectively, after the adsorption of $\mathrm{Pb}^{2+}$, $\mathrm{Cu}^{2+}$, and $\mathrm{Cd}^{2+}$, indicating that the oxygen groups of on mp-CA/GO were involved in chemisorption of $\mathrm{Pb}^{2+}, \mathrm{Cu}^{2+}$, and $\mathrm{Cd}^{2+}$. Therefore, the excellent adsorption performance of mp-CA/GO is attributed to the combined action of chemical coordination and ion exchange.
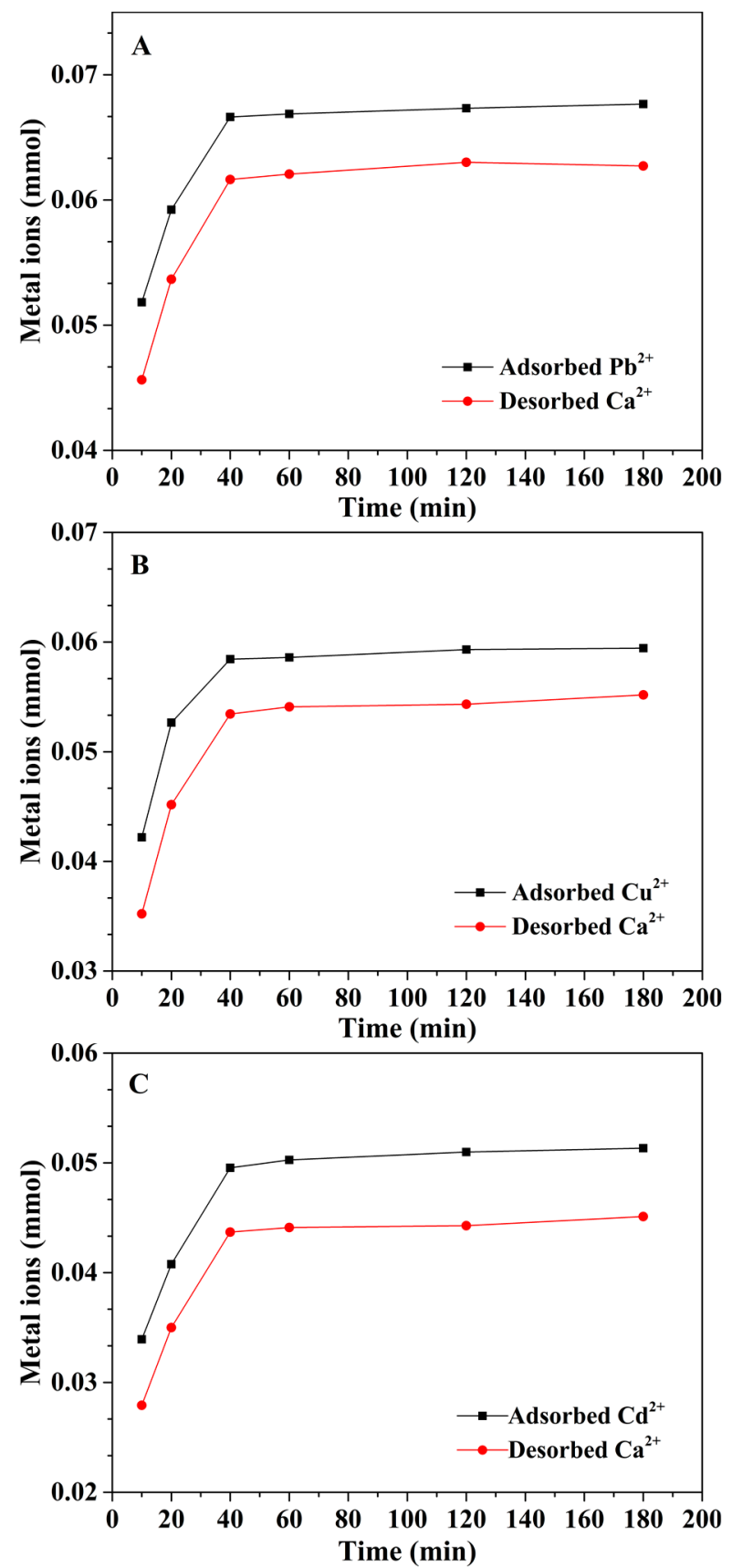

Figure 9. The mole amount of $(\mathbf{A}) \mathrm{Pb}^{2+}, \mathrm{Ca}^{2+},(\mathbf{B}) \mathrm{Cu}^{2+}, \mathrm{Ca}^{2+}$ and (C) $\mathrm{Cd}^{2+}, \mathrm{Ca}^{2+}$ in different adsorption times. 

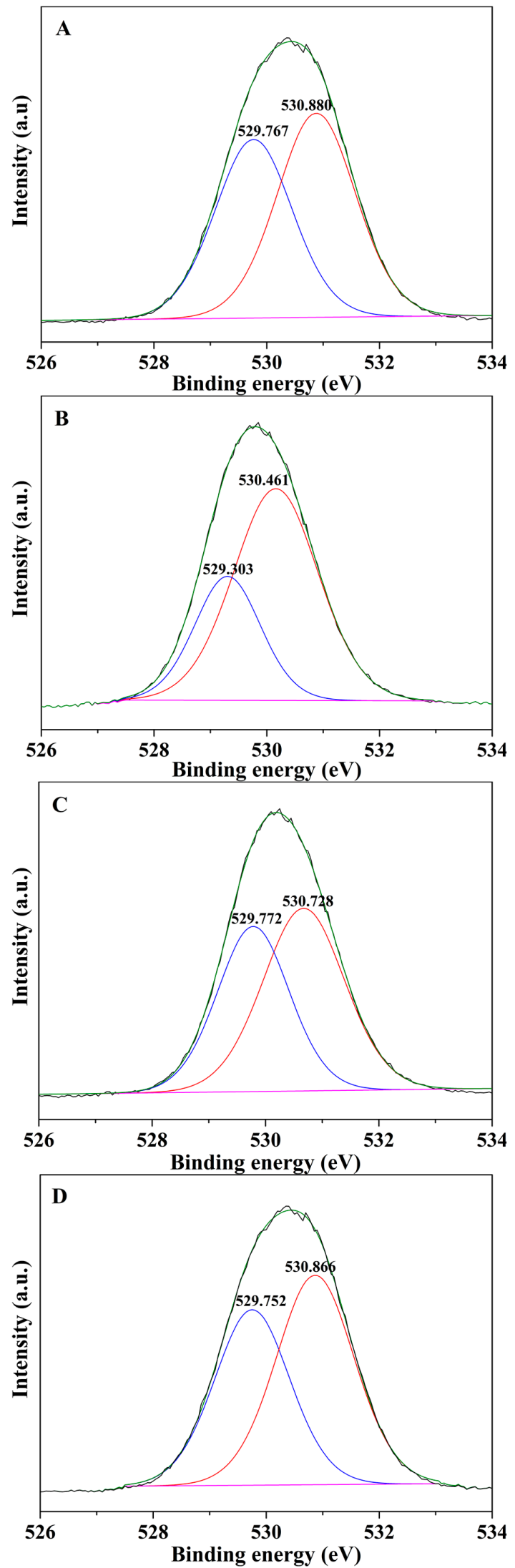

Figure 10. O1s XPS spectra of (A) mp-CA/GO, (B) mp-CA/GO with $\mathrm{Pb}^{2+}$ adsorption, (C) mp-CA/GO with $\mathrm{Cu}^{2+}$ adsorption, and (D) mp-CA/GO with $\mathrm{Cd}^{2+}$ adsorption. 


\subsection{Regeneration Research}

In the regeneration process, the mp-CA/GOs that were individually loaded with $\mathrm{Pb}^{2+}, \mathrm{Cu}^{2+}$, and $\mathrm{Cd}^{2+}$ were immersed into $50 \mathrm{~mL}$ of $0.07 \mathrm{M} \mathrm{HNO}_{3}$ solution. Then, the mp-CA/GO was separated and washed sequentially with DI water, calcium hydroxide solution, and then DI water till the final eluent to neutral.

The recyclability of mp-CA/GO is depicted in Figure 11. The mp-CA/GO could remove $\mathrm{Pb}^{2+}$, $\mathrm{Cu}^{2+}$ and $\mathrm{Cd}^{2+}$ after 20 adsorption-desorption cycles with a performance loss within five \%, possibly attributed to the GO, as reinforcing fillers, to maintain the mechanical strength and elasticity of $\mathrm{mp}-\mathrm{CA} / \mathrm{GO}$ during the continuous adsorption-desorption process.

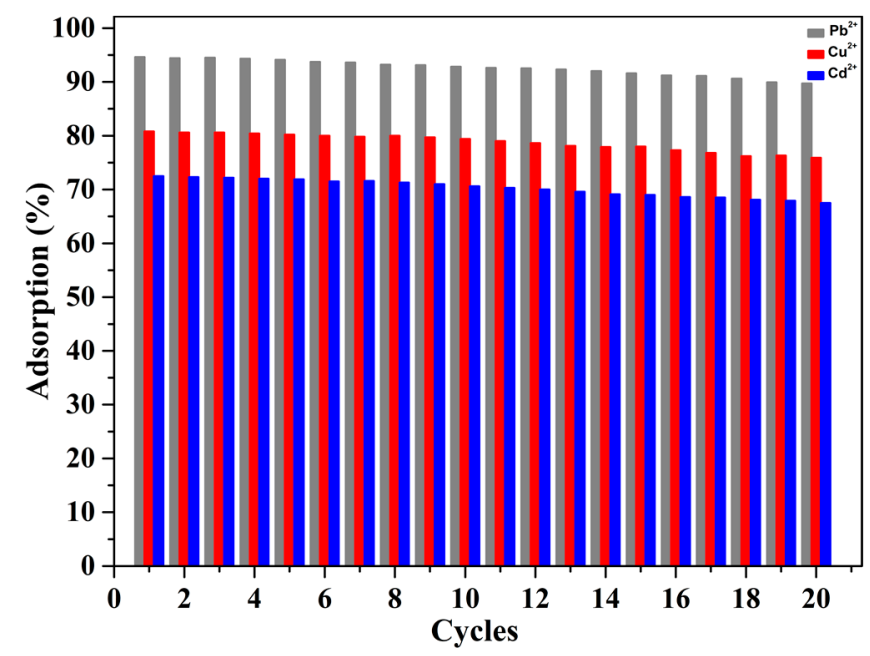

Figure 11. Regeneration research of mp-CA/GO. ( $50 \mathrm{mg}$ of mp-CA/GO and $1.5 \mathrm{mM}$ of $\mathrm{Pb}^{2+}$ solution were used here).

\section{Conclusions}

In this study, the mp-CA/GO with controlled pore structure was used as an efficient solid adsorbent to remove heavy metal ion in wastewater. The fabrication of a controlled porous structure has two advantages. First, the porous structure increases the surface area of the material itself, thereby enabling the adsorbent material to provide additional binding sites for heavy metal ions. The removal rates for $\mathrm{Pb}^{2+}, \mathrm{Cu}^{2+}$, and $\mathrm{Cd}^{2+}$ were $95.4 \%, 81.2 \%$, and $73.2 \%$, respectively. Second, existing porous structure significantly accelerates the diffusion rate of ions in the adsorption process, thus enabling the adsorption process to complete within $40 \mathrm{~min}$. Furthermore, the $\mathrm{mp}-\mathrm{CA} / \mathrm{GO}$ could be regenerated through a simple acid washing process and used repeatedly with little loss in performance. Additionally, the wide $\mathrm{pH}$ application range and the weak sensitivity to temperature also allowed the mp-CA/GO to be potentially applied to actual heavy metal sewage treatment.

Author Contributions: Z.W. and L.P. conceived and designed the experiments; L.P. performed the experiments; L.P. and Q.Y. analyzed the data; Z.W. and L.P. wrote the paper; R.H. made revisions of the manuscript.

Acknowledgments: We gratefully acknowledge the national natural science foundation of China (21407004), Anhui province office of education (KJ2017A345) and Program for Innovative Research Team in Anqing Normal University for financial support.

Conflicts of Interest: The authors declare no conflict of interest.

\section{References}

1. Volesky, B. Detoxification of metal-bearing effluents: Biosorption for the next century. Hydrometallurgy 2001, 59, 203-216. [CrossRef]

2. Voisin, H.; Bergstrom, L.; Liu, P.; Mathew, A.P. Nanocellulose-based materials for water purification. Nanomaterials 2017, 7, 57. [CrossRef] [PubMed] 
3. Babel, S.; Kurniawan, T.A. Low-cost adsorbents for heavy metals uptake from contaminated water: A review. J. Hazard. Mater. 2003, 97, 219-243. [CrossRef]

4. Wang, Z.Q.; Wu, A.G.; Ciacchi, L.C.; Wei, G. Recent advances in nanoporous membranes for water purification. Nanomaterials 2018, 8, 65. [CrossRef] [PubMed]

5. Cataldo, S.; Lazzara, G.; Massaro, M.; Muratore, N.; Pettignano, A.; Riela, S. Functionalized halloysite nanotubes for enhanced removal of lead(II) ions from aqueous solutions. Appl. Clay Sci. 2018, 156, 87-95. [CrossRef]

6. Hepel, M.; Dentrone, L. Controlled incorporation of heavy metals from aqueous solutions and their electrorelease using composite polypyrrole films. Electroanalysis 1996, 8, 996-1005. [CrossRef]

7. Hepel, M.; Zhang, X.M.; Stephenson, R.; Perkins, S. Use of electrochemical quartz crystal microbalance technique to track electrochemically assisted removal of heavy metals from aqueous solutions by cation-exchange composite polypyrrole-modified electrodes. Microchem. J. 1997, 56, 79-92. [CrossRef]

8. Cavallaro, G.; Gianguzza, A.; Lazzara, G.; Milioto, S.; Piazzese, D. Alginate gel beads filled with halloysite nanotubes. Appl. Clay Sci. 2013, 72, 132-137. [CrossRef]

9. Deze, E.G.; Papageorgiou, S.K.; Favvas, E.P.; Katsaros, F.K. Porous alginate aerogel beads for effective and rapid heavy metal sorption from aqueous solutions: Effect of porosity in $\mathrm{Cu}^{2+}$ and $\mathrm{Cd}^{2+}$ ion sorption. Chem. Eng. J. 2012, 209, 537-546. [CrossRef]

10. Wang, Z.Q.; Huang, Y.G.; Wang, M.; Wu, G.H.; Geng, T.M.; Zhao, Y.G.; Wu, A.G. Macroporous calcium alginate aerogel as sorbent for $\mathrm{Pb}^{2+}$ removal from water media. J. Environ. Chem. Eng. 2016, 4, 3185-3192. [CrossRef]

11. Wang, Z.Q.; Jin, P.X.; Wang, M.; Wu, G.H.; Sun, J.Y.; Zhang, Y.J.; Dong, C.; Wu, A.G. Highly efficient removal of toxic $\mathrm{Pb}^{2+}$ from wastewater by an alginate-chitosan hybrid adsorbent. J. Chem. Technol. Biot. 2018, 93, 2691-2700. [CrossRef]

12. Lagoa, R.; Rodrigues, J.R. Kinetic analysis of metal uptake by dry and gel alginate particles. Biochem. Eng. J. 2009, 46, 320-326. [CrossRef]

13. Jiao, C.L.; Xiong, P.G.; Tao, J.; Xu, S.J.; Zhang, D.S.; Lin, H.; Chen, Y.Y. Sodium alginate/graphene oxide aerogel with enhanced strength-toughness and its heavy metal adsorption study. Int. J. Biol. Macromol. 2016, 83, 133-141. [CrossRef] [PubMed]

14. Yang, X.Z.; Zhou, T.Z.; Ren, B.Z.; Hursthouse, A.; Zhang, Y.Z. Removal of Mn(II) by sodium alginate/graphene oxide composite double-network hydrogel beads from aqueous solutions. Sci. Rep. 2018, 8, 10717. [CrossRef] [PubMed]

15. Lui, G.; Li, G.; Wang, X.L.; Jiang, G.P.; Lin, E.; Fowler, M.; Yu, A.P.; Chen, Z.W. Flexible, three-dimensional ordered macroporous $\mathrm{TiO}_{2}$ electrode with enhanced electrode electrolyte interaction in high-power li-ion batteries. Nano Energy 2016, 24, 72-77. [CrossRef]

16. Choi, B.G.; Yang, M.; Hong, W.H.; Choi, J.W.; Huh, Y.S. 3D macroporous graphene frameworks for supercapacitors with high energy and power densities. Acs Nano 2012, 6, 4020-4028. [CrossRef] [PubMed]

17. Kim, D.Y.; Kim, M.; Kim, D.W.; Suk, J.; Park, J.J.; Park, O.O.; Kang, Y. Graphene paper with controlled pore structure for high-performance cathodes in $\mathrm{LiO}_{2}$ batteries. Carbon 2016, 100, 265-272. [CrossRef]

18. Song, N.J.; Chen, C.M.; Lu, C.X.; Liu, Z.; Kong, Q.Q.; Cai, R. Thermally reduced graphene oxide films as flexible lateral heat spreaders. J. Mater. Chem. A 2014, 2, 16563-16568. [CrossRef]

19. Xiao, F.; Yang, S.X.; Zhang, Z.Y.; Liu, H.F.; Xiao, J.W.; Wan, L.; Luo, J.; Wang, S.; Liu, Y.Q. Scalable synthesis of freestanding sandwich-structured graphene/polyaniline/graphene nanocomposite paper for flexible all-solid-state supercapacitor. Sci. Rep. 2015, 5, 9359. [CrossRef] [PubMed]

20. He, Y.Q.; Zhang, N.N.; Gong, Q.J.; Qiu, H.X.; Wang, W.; Liu, Y.; Gao, J.P. Alginate/graphene oxide fibers with enhanced mechanical strength prepared by wet spinning. Carbohydr. Polym. 2012, 88, 1100-1108. [CrossRef]

21. Maria, H.; Dustin, B.; Matthew, M.; Magdalena, S.; Kaitlin, C. Assembly of Gold Nanoparticles Induced by Metal Ions. In Functional Nanoparticles for Bioanalysis, Nanomedicine, and Bioelectronic Devices; Hepel, M., Zhong, C.J., Eds.; ACS Symposium Series; Oxford University Press: Oxford, UK, 2012; Volume 1, pp. 207-240.

22. Braccini, I.; Perez, S. Molecular basis of $\mathrm{Ca}^{2+}$-induced gelation in alginates and pectins: The egg-box model revisited. Biomacromolecules 2001, 2, 1089-1096. [CrossRef] [PubMed]

23. Wan, Y.Z.; Chen, X.Q.; Xiong, G.Y.; Guo, R.S.; Luo, H.L. Synthesis and characterization of three-dimensional porous graphene oxide/sodium alginate scaffolds with enhanced mechanical properties. Mater. Express 2014, 4, 429-434. [CrossRef] 
24. Huang, Y.G.; Wang, Z.Q. Preparation of composite aerogels based on sodium alginate, and its application in removal of $\mathrm{Pb}^{2+}$ and $\mathrm{Cu}^{2+}$ from water. Int. J. Biol. Macromol. 2018, 107, 741-747. [CrossRef] [PubMed]

25. Heidari, A.; Younesi, H.; Mehraban, Z. Removal of $\mathrm{Ni}(\mathrm{II}), \mathrm{Cd}(\mathrm{II})$, and $\mathrm{Pb}(\mathrm{II})$ from a ternary aqueous solution by amino functionalized mesoporous and nano mesoporous silica. Chem. Eng. J. 2009, 153, 70-79. [CrossRef]

26. Afkhami, A.; Saber-Tehrani, M.; Bagheri, H. Simultaneous removal of heavy-metal ions in wastewater samples using nano-alumina modified with 2,4-dinitrophenylhydrazine. J. Hazard. Mater. 2010, 181, 836-844. [CrossRef] [PubMed]

27. Guo, X.Y.; Du, B.; Wei, Q.; Yang, J.; Hu, L.H.; Yan, L.G.; Xu, W.Y. Synthesis of amino functionalized magnetic graphenes composite material and its application to remove $\mathrm{Cr}(\mathrm{VI}), \mathrm{Pb}(\mathrm{II}), \mathrm{Hg}(\mathrm{II}), \mathrm{Cd}(\mathrm{II})$ and $\mathrm{Ni}(\mathrm{II})$ from contaminated water. J. Hazard. Mater. 2014, 278, 211-220. [CrossRef] [PubMed]

28. Zhang, Q.R.; Yang, Q.G.; Phanlavong, P.; Li, Y.X.; Wang, Z.K.; Jiao, T.F.; Peng, Q.M. Highly efficient lead(II) sequestration using size-controllable polydopamine microspheres with superior application capability and rapid capture. ACS Sustain. Chem. Eng. 2017, 5, 4161-4170. [CrossRef]

29. Chu, L.; Liu, C.B.; Zhou, G.Y.; Xu, R.; Tang, Y.H.; Zeng, Z.B.; Luo, S.L. A double network gel as low cost and easy recycle adsorbent: Highly efficient removal of $\mathrm{Cd}(\mathrm{II})$ and $\mathrm{Pb}(\mathrm{II})$ pollutants from wastewater. J. Hazard. Mater. 2015, 300, 153-160. [CrossRef] [PubMed]

30. Do, X.H.; Lee, B.K. Removal of $\mathrm{Pb}^{2+}$ using a biochar-alginate capsule in aqueous solution and capsule regeneration. J. Environ. Manage. 2013, 131, 375-382. [CrossRef] [PubMed]

31. Jiang, N.N.; Xu, Y.T.; Dai, Y.Q.; Luo, W.A.; Dai, L.Z. Polyaniline nanofibers assembled on alginate microsphere for $\mathrm{Cu}^{2+}$ and $\mathrm{Pb}^{2+}$ uptake. J. Hazard. Mater. 2012, 215, 17-24. [CrossRef] [PubMed]

32. Zhang, S.; Xu, F.; Wang, Y.F.; Zhang, W.Z.; Peng, X.L.; Pepe, F. Silica modified calcium alginate-xanthan gum hybrid bead composites for the removal and recovery of pb(ii) from aqueous solution. Chem. Eng. J. 2013, 234, 33-42. [CrossRef]

33. Cataldo, S.; Gianguzza, A.; Milea, D.; Muratore, N.; Pettignano, A. Pb(II) adsorption by a novel activated carbon-alginate composite material. A kinetic and equilibrium study. Int. J. Biol. Macromol. 2016, 92, 769-778. [CrossRef] [PubMed]

34. Cheraghali, R.; Tavakoli, H.; Sepehrian, H. Preparation, characterization and lead sorption performance of alginate-SBA-15 composite as a novel adsorbent. Sci. Iran. 2013, 20, 1028-1034.

35. Liu, D.G.; Li, Z.H.; Li, W.; Zhong, Z.R.; Xu, J.Q.; Ren, J.J.; Ma, Z.S. Adsorption behavior of heavy metal ions from aqueous solution by soy protein hollow microspheres. Ind. Eng. Chem. Res. 2013, 52, 11036-11044. [CrossRef]

36. Idris, A.; Ismail, N.S.M.; Hassan, N.; Misran, E.; Ngomsik, A.F. Synthesis of magnetic alginate beads based on maghemite nanoparticles for $\mathrm{Pb}(\mathrm{II})$ removal in aqueous solution. J. Ind. Eng. Chem. 2012, 18, 1582-1589. [CrossRef]

37. Rajput, S.; Singh, L.P.; Pittman, C.U.; Mohan, D. Lead $\left(\mathrm{Pb}^{2+}\right)$ and copper $\left(\mathrm{Cu}^{2+}\right)$ remediation from water using superparamagnetic maghemite $\left(\gamma-\mathrm{Fe}_{2} \mathrm{O}_{3}\right)$ nanoparticles synthesized by flame spray pyrolysis. J. Colloid Interface Sci. 2017, 492, 176-190. [CrossRef] [PubMed]

38. Wang, Y.H.; Li, L.L.; Luo, C.N.; Wang, X.J.; Duan, H.M. Removal of $\mathrm{Pb}^{2+}$ from water environment using a novel magnetic chitosan/graphene oxide imprinted $\mathrm{Pb}^{2+}$. Int. J. Biol. Macromol. 2016, 86, 505-511. [CrossRef] [PubMed]

39. Mousa, N.E.; Simonescu, C.M.; Patescu, R.E.; Onose, C.; Tardei, C.; Culita, D.C.; Oprea, O.; Patroi, D.; Lavric, $\mathrm{V} . \mathrm{Pb}^{2+}$ removal from aqueous synthetic solutions by calcium alginate and chitosan coated calcium alginate. React. Funct. Polym. 2016, 109, 137-150. [CrossRef]

40. Lei, Y.; Guan, J.J.; Chen, W.; Ke, Q.F.; Zhang, C.Q.; Guo, Y.P. Fabrication of hydroxyapatite/chitosan porous materials for $\mathrm{Pb}$ (II) removal from aqueous solution. RSC Adv. 2015, 5, 25462-25470. [CrossRef]

41. Marzo, A.M.L.; Pons, J.; Merkoci, A. Multifunctional system based on hybrid nanostructured rod formation, for sensoremoval applications of $\mathrm{Pb}^{2+}$ as a model toxic metal. J. Mater. Chem. A 2013, 1, 13532-13541.

42. Lopez-Marzo, A.M.; Pons, J.; Merkoci, A. Extremely fast and high $\mathrm{Pb}^{2+}$ removal capacity using a nanostructured hybrid material. J. Mater. Chem. A 2014, 2, 8766-8772. [CrossRef]

43. Li, K.T.; Wu, G.H.; Wang, M.; Zhou, X.H.; Wang, Z.Q. Efficient removal of lead ions from water by a low-cost alginate-melamine hybrid sorbent. Appl. Sci. 2018, 8, 1518. [CrossRef] 
(C) 2018 by the authors. Licensee MDPI, Basel, Switzerland. This article is an open access article distributed under the terms and conditions of the Creative Commons Attribution (CC BY) license (http:/ / creativecommons.org/licenses/by/4.0/). 